\title{
A Comparative Study of the Chemical Composition of the Extracts from Leaves, Stem, Bark, and Root Bark of Cassia sieberiana: Antibacterial Activities
}

\section{KAFUI KPEGBA ${ }^{1}$, KODJO ELOH $^{2}$, KODJO SELOM EVENAMEDE $^{1 *}$, YAOVI-GAMELI AFANYIBO ${ }^{3}$, ABDELHAKIM ELOMRI', OUDJANIYOBI SIMALOU', PAKOUPATI BOYODE', AMEGNONA AGBONON and ELISABETH SEGUIN ${ }^{5}$}

'Laboratoire de Chimie Organique et des Substances Naturelles (Lab COSNat), Faculté des Sciences, Université de Lomé, 01 BP 1515 Lomé 01, Lomé-Togo.

${ }^{2}$ Department of Life and Environmental Sciences, University of Cagliari, Via Ospedale 72, 09124 , Cagliari, Italy.

${ }^{3}$ Institut National d'Hygiène (INH) de Lomé, BP:1396 Lomé, Togo.

${ }^{4}$ Laboratoire de Physiologie/Pharmacologie, Faculté des Sciences, Université de Lomé;

01 BP 1515 Lomé 01, Lomé, Togo.

${ }^{5}$ Normandie Universite, UNIROUEN, INSA Rouen, CNRS, COBRA (UMR 6014), 76000 Rouen, France.

${ }^{*}$ Corresponding author E-mail: ev_selom@yahoo.fr

http://dx.doi.org/10.13005/ojc/350608

(Received: October 18, 2019; Accepted: December 21, 2019)

\begin{abstract}
In Togo, the abusive use of the root of Cassia sieberiana D.C. in traditional medicine, contributes gradually to the rarefaction of the species. The general objective of this study is to promote the use of vital organs of Cassia sieberiana in traditional medicine in Togo. The identification of secondary metabolites of the extracts (cyclohexane, dichloromethane and methanol) was carried out by GC-MS and by CL-MS/MS. The antibiotic susceptibility test was performed according to the well diffusion method and the MICs and MBCs according to the tube dilution method. Compounds such as sitosterol $\alpha$-acetate, $\beta$-sitosterol, emodin, chaetochromine, luteolin, $( \pm)$-catechin, naringenin 5-O-rhamnoside, guibourtinidol- (4 alpha-> 6) -catechin and (-) - epiafzelechin are found in the root and in the stem bark. The identified molecules give the different methanolic extracts, an antibacterial effect on all the germs tested. At the end of this study, it appears that the chemical composition of the stem bark is almost similar to that of the root bark. The leaves would be better placed for the treatment of bacteria tested.
\end{abstract}

Keywords: Cassia sieberiana, GC-MS, LC-SM/SM, Chemical composition, Antibacterial activity.

This is an Open Access article licensed under a Creative Commons license: Attribution 4.0 International (CC- BY). Published by Oriental Scientific Publishing Company @ 2018 


\section{INTRODUCTION}

Plants are a major source of compounds. The great diversity of structures of these compounds with a wide variety of biological activities is attributed to secondary metabolites. Today, they play a decisive role in the treatment of various pathologies ${ }^{1}$.

In a number of cases, the valorization of traditional medicine is featured by overexploitation and, therefore, by a decrease in certain plant species because of their excessive use for health care. This is the case of Cassia sieberiana belonging to the Caesalpiniaceae family.

Cassia sieberiana is a widespread plant in West Africa (Senegal, Burkina Faso, Benin, Mali, Togo, etc.). It can also be found in the Democratic Republic of Congo and in Uganda ${ }^{2}$. In traditional medicine, it is frequently used for the treatment of various pathologies such as malaria, hot flashes in menopausal women, hemorrhoids, abdominal pain, sexual impotence, leprosy, headaches, jaundice, female sterility ${ }^{3,4}$, diabetes ${ }^{5}$ and HIV ${ }^{6}$. Previous studies have shown that the ethanolic extract of the root of Cassia sieberiana has an antiparasitic, myorelaxant, antispasmodic ${ }^{7}$ and antioxidant effect ${ }^{4,8}$. They have also shown that extracts of $C$. sieberiana have antiviral properties against herpes simplex virus type I and African swine fever virus ${ }^{9}$. Phytochemical work has led to the isolation of molecules from root extracts such as (-) - epiafzelechin ${ }^{4}$.

In Togo, excessive use of the roots of Cassia sieberiana DC in traditional medicine, leads slowly to the reduction in quantity of the species. This can be explained by the fact that to get the roots, sometimes the whole plant is torn off or, if the roots are partially torn off, the plants die because of the lack of roots that support them.

In order to fight the disappearance of this species, it is important to carry out comparative studies to find out whether the use of the stem bark or even the leaves, that is, renewable organs of Cassia sieberiana, instead of its roots for the treatment of the abovementioned pathologies is not more advisable. These studies can be conducted on the three organs belonging to the same plant and harvested under the same conditions. These studies are based on the assumption that Cassia sieberiana leaves contain the same chemical compounds found in the root and in the stem bark.

The general objective of this work is to promote the use of renewable organs of Cassia sieberiana in traditional medicine to help preserve plant biodiversity in Togo.

\section{MATERIAL AND METHODS}

\section{Plant material}

Cassia sieberiana species was harvested in September 2015 in Danyi, in the mountains of Togo, $200 \mathrm{~km}$ northwest of Lome. The plant has been identified (\# 2541) by the Department of Botany at the Faculty of Science, University of Lomé in Togo. The leaves, stem bark and root bark of the plant were then dried, ground into powder and stored away from light and moisture for further analysis.

\section{Preparation of plant extracts}

The different extracts are prepared from dried organs (leaves, bark and root) previously ground. The powder ( $2 \mathrm{~g}$ ) thus obtained is subjected to solid/liquid extraction at room temperature with stirring for $30 \mathrm{~min}$ with the use of solvents of increasing polarity (cyclohexane, dichloromethane). Evaporated to dryness, each extract was then studied through gas chromatography coupled with a mass spectrometer. The methanolic extracts were obtained by maceration: $25 \mathrm{~g}$ of vegetable powder in $250 \mathrm{~mL}$ of methanol. For the performance of the antimicrobial tests, the extracts were sterilized on a Millipore membrane with a diameter of $47 \mathrm{~mm}$ and a porosity of $0.45 \mu \mathrm{m}$.

\section{Comparative study of metabolic extracts from thethree organs through the thin-layer chromatography}

Thin-layer chromatography was performed according to Merk with an eluent consisting of $80 \%$ $\mathrm{CH}_{2} \mathrm{Cl}_{2}$ and $20 \% \mathrm{MeOH}(\mathrm{v} / \mathrm{v})$.

\section{Comparative study of the methanolic extracts of the three organs through DART}

Methanolic extracts of the plant organs were analyzed by a mass spectrometer. Mass spectra were recorded using an AccuTOF (JEOL) equipped with a DART ion source (real-time direct analysis). 
Analytical study through gas chromatographymass spectrometry

Plant extracts were analyzed by a HewlettPackard 6850 gas chromatograph, 5973 mass selective detector, and 7683B series injector (Agilent Technologies, Palo Alto, CA). Helium flow was the carrier gas at the flow of $1 \mathrm{~mL} /$ minute. A total of $1 \mu \mathrm{L}$ of samples was injected in splitless mode and resolved on a $30 \mathrm{~m} \times 0.25 \mathrm{~mm} \times 0.25 \mu \mathrm{m}$ DB5MS column (Agilent Technologies, Palo Alto, CA). The temperatures for the inlet, interface, and ion source were 250,250 , and $230^{\circ} \mathrm{C}$, respectively. The oven temperature was programmed as follows: from 50 to $230^{\circ} \mathrm{C}\left(5^{\circ} \mathrm{C} / \mathrm{min}\right.$ in $\left.36 \mathrm{~min}\right)$ and kept at this temperature for 2 minute. Electron impact $(70 \mathrm{eV})$ mass spectra were recorded from $\mathrm{m} / \mathrm{z} 50$ to 550 . The resulting data were elaborated using MSD ChemStation. Raw data files were exported into the automated mass spectral deconvolution and identification system (AMDIS 2.1) for spectral deconvolution and database-searched against the National Institute of Standards and Technology (NIST) Mass Spectral Database (2.0a) and Golm metabolome database. Confirmation of sample components was performed by (a) comparison of their relative retention times and mass fragmentation to those of pure standards and (b) computer matching against NIST as well as retention indices as calculated according to Kovats for alkanes C9-C36.

\section{Analytical study liquid chromatography coupled with mass spectrometry}

RP-HPLC analysis was performed by an Agilent 1200 series rapid resolution LC system (Agilent Technologies, Palo Alto, CA) consisting of a vacuum degasser, an autosampler, and a binary pump equipped with a reversed-phase $\mathrm{C} 18$ analytical column $(4.6-250 \mathrm{~mm}, 1.8 \mu \mathrm{m}$ particle size, Agilent ZORBAX Eclipse plus). Water and methanol mobile phases and gradient program were as follows: $90 \%$ of water with $0.1 \%$ formic acid to $100 \%$ methanol in 20 minute. All solvents were filtered with a $0.45 \mu \mathrm{m}$ filter disk with a $5 \mathrm{~min}$ re-equilibration time. The column temperature was maintained at $25^{\circ} \mathrm{C}$, and the injection volume was $4 \mu \mathrm{L}$. The RP-HPLC system was coupled with a quadrupole and an orthogonal accelerated time-of-flight mass spectrometer (QTOF-MS) equipped with an ESI interface. Parameters for analysis were set using positive ion mode with spectra acquired over a mass range from $\mathrm{m} / \mathrm{z} 50$ to 1500 . The optimum values of the ESI-MS parameters were capillary voltage, -4.5 $\mathrm{kV}$; drying gas temperature, $210^{\circ} \mathrm{C}$; drying gas flow, $10.0 \mathrm{~L} / \mathrm{min}$; and nebulizing gas pressure, $21.7 \mathrm{psi}$.

\section{Antibacterial test Microbial strains \\ The microorganisms under study} consisted of five reference strains and five hospital strains similar to the reference strains. They are Staphylococcus aureus ATCC 29213 a Grampositive bacterium, Escherichia coli ATCC 25922, Salmonella typhimurium ATCC 14028, Klebsiella pneumoniae ATCC 13883 Gram-negative bacteria and Candida albicans ATCC 35659 which is yeast. All these strains were provided by the bacteriology laboratory of the Togolese National Institute for Hygiene (INH). Hospital strains come from samples of pus, stool, urine and vaginal secretions. They have been isolated again in natural cultures and identified before their use. The reference strains obtained in freeze-dried form were rehydrated with Trypticase Soy Broth and then isolated in pure cultures before their use.

\section{Sensitivity test}

The inoculum was prepared from a young colony of $24 \mathrm{~h}$ emulsified in $10 \mathrm{~mL}$ of Bouillon Muller Hinton (BMH). The density of the inoculum was adjusted to 0.5 Mac Farland using a densitometer. The antimicrobial activity was performed by the agar diffusion method ${ }^{10,11}$. Petri dishes containing MuellerHinton agar were inoculated with the inoculum in tight streaks by the swab technique. Then, 6-mm-diameter wells excavated in the agar were filled with $50 \mu \mathrm{l}$ of the extract solution at a concentration of $100 \mathrm{mg} / \mathrm{mL}^{11}$. After $30 \mathrm{~min}$ of pre-diffusion at laboratory temperature, the whole was incubated at $37^{\circ} \mathrm{C}$. for 24 hours. Candida albicans was incubated at $25^{\circ} \mathrm{C}$. The inhibition diameter around each well was measured using an electronic reading chart (vernier caliper). Sterile distilled water was used as a negative control. Gentamicin and nystatin were used as positive controls for bacteria and yeast, respectively. The test was performed in Triplicate. The effectiveness of the extracts was evaluated according to the criterion of Ponce et al., ${ }^{12}$

Determination of Minimal Inhibitory Concentration (MIC) and Minimal Bactericidal Concentration/ Fungicidal Concentration (MBC /MFC)

The determination of the MIC and the MBC was performed through the liquid macro-dilution 
method using hemolysis tubes ${ }^{11,13}$. From a large solution of $100 \mathrm{mg} / \mathrm{mL}$ extract, half $(100-1.56 \mathrm{mg} /$ $\mathrm{mL}$ ) was diluted successively with Mueller-Hinton broth. One microliter $(1 \mu \mathrm{L})$ of a bacterial suspension (105 McFarland) was added to each dilution. The growth control tube got $1 \mathrm{~mL}$ of sterile MuellerHinton broth in addition to the inoculum, while sterility control received only Muller-Hinton Broth. The tubes thus seeded are covered with aluminum foil and incubated for $24 \mathrm{~h}$ at $37^{\circ} \mathrm{C}$ for the bacteria and at $25^{\circ} \mathrm{C}$ for the yeast. After incubation, the tube corresponding to the lowest concentration of extract for which no turbidity is observed is considered MIC of the extract on the strain tested. The tubes that did not exhibit turbidity were seeded on specific agar under the same conditions as previously. The lowest dilution that did not show colonies on seeded plates was considered MBC or MFC depending on whether it is bacteria or yeast. $\mathrm{MBC}$ or $\mathrm{FC}$ is the concentration of the substance which, after incubation at the optimum temperature and duration, yields $0.01 \%$ viable bacteria or yeasts ${ }^{11,14}$.

The extract is active if the inhibition diameter is greater than or equal to $12 \mathrm{~mm}^{11}$. If the ratio $\mathrm{MBC} /$ MIC is less than or equal to 2 , the substance is called bactericidal. On the other hand, if it is greater than 2, the substance is called bacteriostatic. Microbiological results were performed using Graph Pad software to compare the activity of extracts of leaves, bark and root of Cassia sieberiana between them on different strains. The results obtained were expressed as mean \pm standard deviation (SD). The level of significance is $5 \%(p=0.05)$.

\section{RESULTS AND DISCUSSION}

\section{Results}

\section{Comparative study of methanolic extracts from three organs through TLC}

This study shows that there is similarity between the chromatographic profiles of methanolic extracts from the stem bark and root bark. However, the leaves have a different chromatographic profile from the two other organs of the plant (photo1). These preliminary results allowed us to continue our investigation on the stem bark and on the root bark.

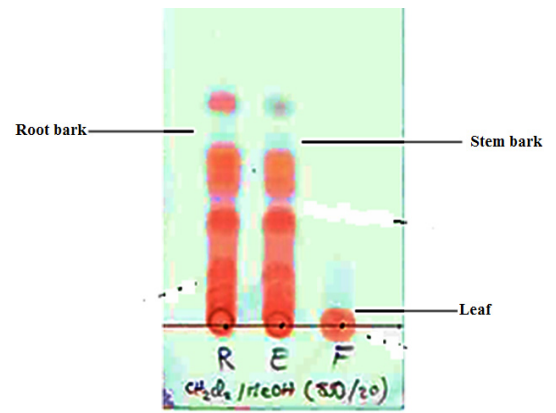

Photo 1. TLC methanolic extracts from the three organs of the plant

\section{Comparative study of methanolic extracts of the} organs of the plant through HPLC

This comparative study of the methanolic extracts through HPLC gives chromatograms recorded in Fig. 1. These chromatograms show that there is indeed similarity between the chromatogram from the stem bark extract and that from the root bark extract. However, the chromatogram of the leaves extract is different from those of the stem bark and root bark extracts.

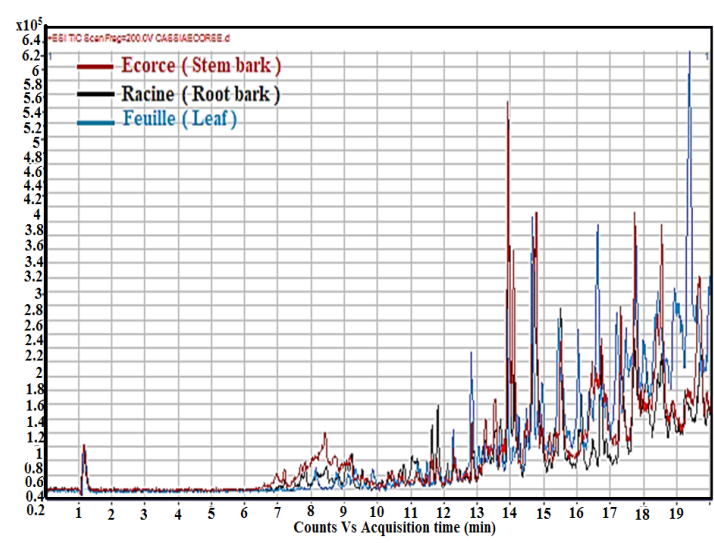

Fig. 1. Superposition of the chromatograms from the methanolic extracts of the three organs of $C$. sieberiana

Comparative study of the methanolic extracts from the three organs (DART)

The realization of the mass spectra of crude extracts (DART: Fig. 2) shows that the three organs of the plant contain molecular compounds which differ from one organ to another. However, these spectra indicate that the root bark and stem bark have several common adducts [M + H] (239.2466; $271.2652 ; 273.2842 ; 289.2846)$. It confirms the results of the TLC (Photo 1) and the chromatogram Figure 1. 


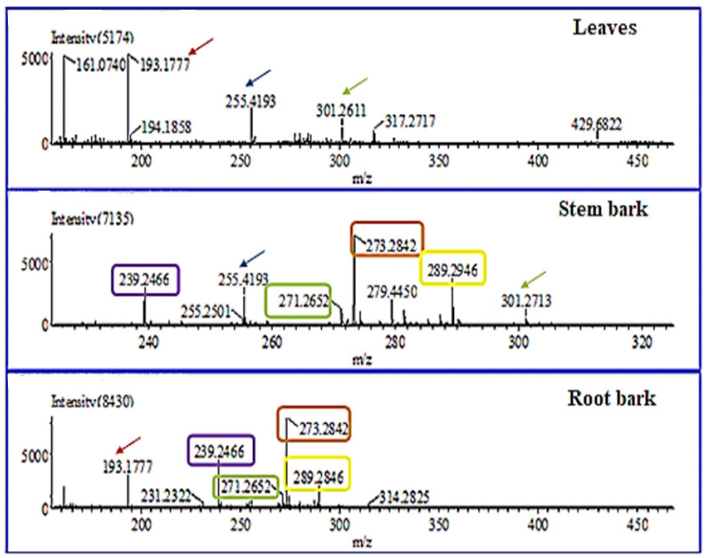

Fig. 2. Mass spectrum (DART-AccuTOF) of ethanolic extracts from $C$. sieberiana leaves, stem bark and root bark

Chemical composition of cyclohexane and dichloromethane extracts

This study showed the difference in chemical composition between the three organs of the plant. Note that all the molecules identified in the cyclohexane and dichloromethane (volatile phase) extracts of the stem bark and root bark are also found in leaf extracts, except for $\alpha$-amyrin, which has been identified only in the root bark (Table 1).
Table 1 : Molecules identified in the cyclohexane and dichloromethane extracts of C. sieberiana by GC-MS

\begin{tabular}{|c|c|c|c|c|}
\hline \multirow[t]{2}{*}{ No. } & \multirow[t]{2}{*}{ Identified molecules } & \multicolumn{3}{|c|}{ Organs of the plant } \\
\hline & & Leaf & $\begin{array}{l}\text { Root } \\
\text { bark }\end{array}$ & $\begin{array}{l}\text { Stem } \\
\text { bark }\end{array}$ \\
\hline 1 & Lupeol & I & I & $\mathrm{NI}$ \\
\hline 2 & Stigmasterol & I & I & $\mathrm{NI}$ \\
\hline 3 & $\beta$-Sitosterol & I & I & I \\
\hline 4 & $\begin{array}{l}\alpha \text {-Sitosterol } \\
\text { acetate }\end{array}$ & I & I & I \\
\hline 5 & $\begin{array}{l}\text { Vitamin E (alpha- } \\
\text { tocopherol) }\end{array}$ & I & $\mathrm{NI}$ & $\mathrm{NI}$ \\
\hline 6 & $\begin{array}{l}\text { Taraxerone (D-Friedoolean- } \\
\text { 14-en-3-one) }\end{array}$ & I & $\mathrm{NI}$ & $\mathrm{NI}$ \\
\hline 7 & Lup-20(29)-en-3-one & I & $\mathrm{NI}$ & $\mathrm{NI}$ \\
\hline 8 & Squalene & I & $\mathrm{NI}$ & $\mathrm{NI}$ \\
\hline 9 & $\begin{array}{l}(3-\beta) \text {-stigmasta-5,22-dien- } \\
\text { 3-ol acetate }\end{array}$ & 1 & $\mathrm{NI}$ & $\mathrm{NI}$ \\
\hline 10 & $\begin{array}{l}2,6,10,14,18 \text {-pentamethyleicosa- } \\
2,6,10,14,18 \text { - pentaene }\end{array}$ & I & $\mathrm{NI}$ & $\mathrm{NI}$ \\
\hline 11 & $\begin{array}{l}\text { 24- (2-Methylpropylidene) cholesta- } \\
\text { 5,7-dien-3-ol acetate }\end{array}$ & -1 & $\mathrm{NI}$ & $\mathrm{NI}$ \\
\hline 12 & Campesterol & I & I & $\mathrm{NI}$ \\
\hline 13 & $\alpha$-Amyrin & $\mathrm{NI}$ & I & $\mathrm{NI}$ \\
\hline
\end{tabular}

I : Identified ; NI : Not identified

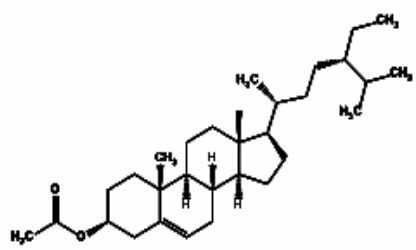

(1) Aphe stitosternol acetate

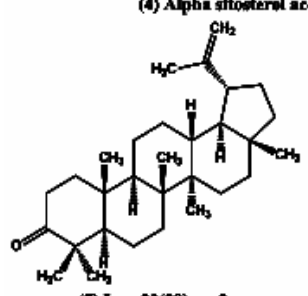

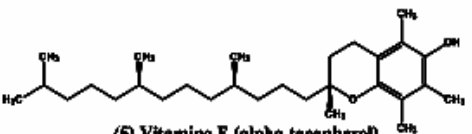

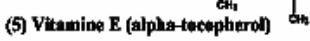<smiles>CCC(CC)CCCC(CC)CCCC(CC)CCCCC(C)CCCCC(C)CCCC(C)C</smiles><smiles>CC1(C)CC[C@]2(C)CCC(=O)C(C)(C)C2C1</smiles>

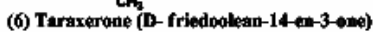

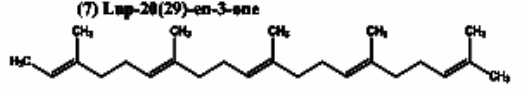

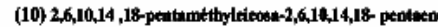

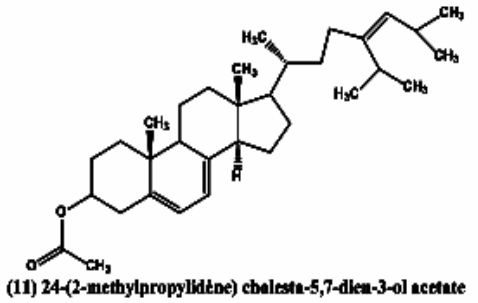

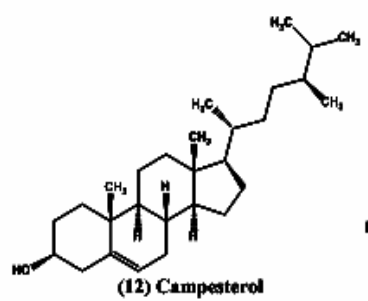

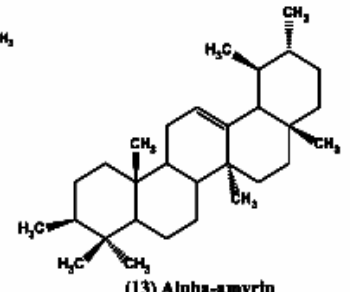

(13) Alphn-anyrtn

Fig. 3. Structures of the identified molecules in the cyclohexane and dichloromethane extracts of $C$. sieberiana through GC-MS 


\section{Chemical composition of methanolic extracts}

The chemical characterization of certain non-volatile compounds from the methanolic extracts of the bark and root of the same plant was done through LC-MS/MS. The results from this analysis are shown in Fig. 4. This study allowed to identify seven (7) phenolic compounds namely: emodin, luteolin, $( \pm)$-catechin, naringenin 5-O-rhamnoside, chaetochromin, guibourdinol(4-alpha-> 6) -catechin, (-) -epiafzelechin. All these compounds are found in both the bark and the root. They belong to either the flavonoid family or the anthraquinone family (emodin) and all have proven biological activities.

Table 2 : Names of identified molecules in the methanolic extracts of the root bark and the stem bark of $\boldsymbol{C}$. sieberiana

\begin{tabular}{|c|c|c|c|c|c|c|}
\hline No & $\begin{array}{l}\text { Name of identified } \\
\text { molecules }\end{array}$ & $\begin{array}{l}\text { Isotopic calculated } \\
\text { adduct } \mathrm{M}+\mathrm{H}\end{array}$ & $\begin{array}{l}\text { Isotopic calculated } \\
\text { adduct } \mathrm{M}+\mathrm{H}\end{array}$ & $\begin{array}{l}\text { Molecular } \\
\text { formula }\end{array}$ & Root bark & Stem bark \\
\hline 1 & Emodin & 271.0601 & 271.0604 & $\mathrm{C}_{15} \mathrm{H}_{10} \mathrm{O}_{5}$ & 1 & 1 \\
\hline 2 & Luteolin & 287.0550 & 287.0547 & $\mathrm{C}_{15}^{15} \mathrm{H}_{10}^{10} \mathrm{O}_{6}^{5}$ & 1 & 1 \\
\hline 3 & $( \pm)$-Catechin & 291.0863 & 291.0868 & $\mathrm{C}_{15}^{15} \mathrm{H}_{14}^{10} \mathrm{O}_{6}^{6}$ & 1 & 1 \\
\hline 4 & naringenin 5 -O-rhamnoside & 419.1336 & 419.1320 & ${ }_{2}^{4} \mathrm{O}_{9}^{6}$ & i & 1 \\
\hline 5 & Chaetochromin & 546,528 & 547.1577 & $\mathrm{C}_{30}^{21} \mathrm{H}$ & I & I \\
\hline 6 & Guibourtinidol-(4 alpha->6) -catechin & 547.1598 & 547.1597 & & 1 & 1 \\
\hline 7 & (-)- epiafzelechin & 275.0914 & 275.0905 & $\mathrm{C}_{15}^{30} \mathrm{H}_{14}^{26} \mathrm{O}_{5}$ & 1 & 1 \\
\hline
\end{tabular}

I: Identified<smiles>Cc1cc(O)c2c(c1)C(=O)c1c(O)cc(O)cc1C2=O</smiles>

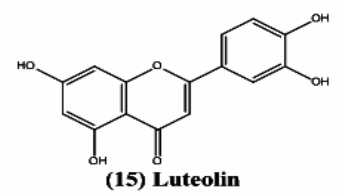

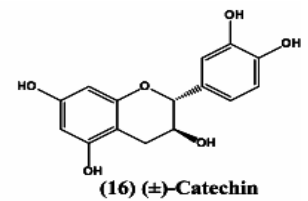

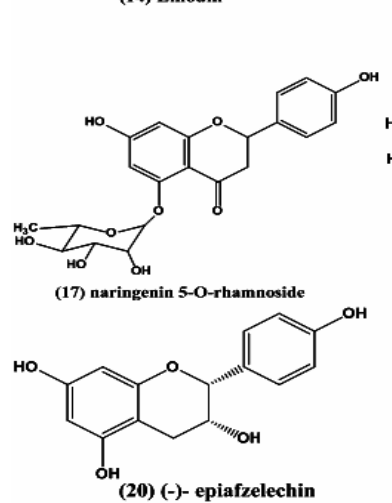

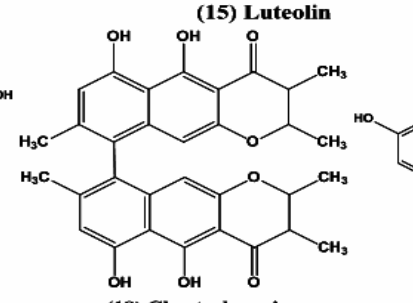

(18) Chaetochromin<smiles>Cc1ccc2c(c1)OC(c1ccc(F)cc1)[C@H](O)[C@@H]2c1c(O)cc2c(c1C)C[C@H](C)[C@H](c1ccc(O)c(O)c1)O2</smiles>

(19) Guibourtinidol-(4 alpha->6) -catechin

Fig. 4. Structure of the identified molecules in the methanolic extracts of the root bark and the stem bark of $\boldsymbol{C}$. sieberiana.

Table 3: Summary of identified molecules in the root bark and stem bark of $C$. sieberiana

\begin{tabular}{|c|c|c|c|}
\hline \multirow[t]{2}{*}{ NO } & \multirow[t]{2}{*}{ Identified molecules } & \multicolumn{2}{|c|}{ Organs of the plant } \\
\hline & & Root bark & stem bark \\
\hline 1 & Lupeol & I & $\mathrm{NI}$ \\
\hline 2 & Stigmasterol & I & $\mathrm{NI}$ \\
\hline 3 & $\beta$-sitosterol & I & I \\
\hline 4 & $\alpha$ - sitosterol acetate & I & I \\
\hline 12 & Campesterol & I & $\mathrm{NI}$ \\
\hline 13 & $\alpha$-amyrin & I & $\mathrm{NI}$ \\
\hline 14 & Emodin & I & I \\
\hline 15 & Luteolin & I & I \\
\hline 16 & $( \pm)$-Catechin & I & I \\
\hline 17 & Naringenin 5-O-rhamnoside & I & I \\
\hline 10 & Chaetochromin & I & I \\
\hline 19 & Guibourtinidol-(4 alpha->6) -catechin & I & I \\
\hline 20 & (-)- Epiafzelechin & I & I \\
\hline
\end{tabular}

I: Identified; NI: Not Identified.

\section{Antimicrobial activities of methanolic extracts} from Cassia sieberiana Sensibility test of methanolic extracts

The presumptive test has globally shown that the extracts show antimicrobial activities in a variable manner vis-à-vis the strains tested. The extract of the leaves is active on $S$. aureus, $S$. typhimurium, $K$. pneumoniae and $C$. albicans. He also presented a non-significant activity on E. coli. The extract of the root bark is active on $S$. aureus, $S$. typhimurium, $K$. pneumoniae and on E. coli. The bark extract is only active on S. aureus and K. pneumoniae (Table 3). The extract is active if the inhibition diameter is greater than or equal to $12 \mathrm{~mm}^{11}$. 
Table 4 : Sensitivity of methanolic extracts of Cassia sieberiana on tested germs

\begin{tabular}{|c|c|c|c|c|c|c|}
\hline Microorganisms & Root bark & Stem bark & Leaf & GM & NYS & $\mathrm{H}_{2} \mathrm{O}$ \\
\hline Staphylococcus aureus ATCC 29213 & $19,50 \pm 0,03$ & $19,66 \pm 0,02$ & $22,50 \pm 0,05$ & $18,74 \pm 0,01$ & - & 0,00 \\
\hline Staphylococcus aureus SH & $19,50 \pm 0,05$ & $19,50 \pm 0,10$ & $22,20 \pm 0,06$ & $17,00 \pm 0,00$ & - & 0,00 \\
\hline Escherichia coli ATCC 25922 & 0,00 & 0,00 & $8,30 \pm 0,50$ & $18,66 \pm 0,03$ & - & 0,00 \\
\hline Escherichia coli HS & 0,00 & 0,00 & $8,00 \pm 0,60$ & $16,00 \pm 0,03$ & - & 0,00 \\
\hline Salmonella typhimurium ATCC 14028 & $12,10 \pm 0,04$ & $8,20 \pm 0,30$ & $18,50 \pm 0,20$ & $20,20 \pm 0$ & - & 0,00 \\
\hline Salmonella typhimurium HS & $12,00 \pm 0,00$ & $8,10 \pm 0,05$ & $15,10 \pm 0,04$ & $20,20 \pm 0$ & - & 0,00 \\
\hline Klebsiella pneumoniae ATCC 13883 & $17,25 \pm 0,04$ & $17,00 \pm 0,00$ & $25,50 \pm 0,15$ & $18,00 \pm 0,51$ & - & 0,00 \\
\hline Klebsiella pneumoniae HS & $16,50 \pm 0,12$ & $16,25 \pm 0,15$ & $20,00 \pm 0,00$ & $15,00 \pm 0,00$ & - & 0,00 \\
\hline Candida albicans ATCC 35659 & 0,00 & 0,00 & $17,85 \pm 0,08$ & - & $16,50 \pm 0,18$ & 0,00 \\
\hline Candida albicans HS & 0,00 & 0,00 & $14,55 \pm 0,07$ & - & $15,90 \pm 0,08$ & 0,00 \\
\hline
\end{tabular}

Values expressed in mean \pm standard deviation. Unit (mm).GM: Gentamicin; NYS: Nystatin

ATCC: American Type Culture Collection. HS: Hospital Strain.

\section{Effect produced by the different types of methanolic} extracts

Table 5 shows the effect types of each extract on the organisms on which they were sensitive to the presumptive test. The results generally show microbicidal effects on extract-sensitive organisms with the exception of the root bark extract which had a bacteriostatic effect on S. typhimurium strains. The leaf extract gives relatively lower MICs and MBCs than those presented by the bark and root extracts.

Table 5: Effect type of methanolic extracts on sensitive Germs

\begin{tabular}{|c|c|c|c|c|c|c|c|c|c|}
\hline \multirow[t]{2}{*}{ Microorganisms } & \multicolumn{3}{|c|}{ Root bark } & \multicolumn{3}{|c|}{ Stem bark } & \multicolumn{3}{|c|}{ Leaf } \\
\hline & MIC & $\mathrm{MBC}$ & Effect & MIC & $\mathrm{MBC}$ & Effect & MIC & $\mathrm{MBC}^{*}$ & Effect \\
\hline Staphylococcus aureus ATCC 29213 & 6,25 & 12,50 & Bactericidal & 3,13 & 12,50 & Bactericidal & 1,56 & 3,13 & Bactericidal \\
\hline Staphylococcus aureus HS & 6,25 & 12,50 & Bactericidal & 3,13 & 25 & Bactericidal & 1,56 & 6,25 & Bactericidal \\
\hline Salmonella typhimurium ATCC 14028 & 6,25 & 6,25 & Bacteriostatic & - & - & - & 6,25 & 12,5 & Bactericidal \\
\hline Salmonella typhimuriumH S & 6,25 & 6,25 & Bacteriostatic & - & - & - & 6,25 & 12,5 & Bactericidal \\
\hline Klebsiella pneumoniae ATCC 13883 & 6,25 & 25 & Bactericidal & 6,25 & 12,50 & Bactericidal & 3,13 & 6,25 & Bactericidal \\
\hline Klebsiella pneumoniae HS & 6,25 & 25 & Bactericidal & 6,25 & 12,50 & Bactericidal & 3,13 & 6,25 & Bactericidal \\
\hline Candida albicans ATCC 35659 & - & - & - & - & - & - & 6,25 & 12,5 & Fungicidal \\
\hline Candida albicans HS & - & - & - & - & - & - & 6,25 & 12,5 & Fungicidal \\
\hline
\end{tabular}

Values expressed in mg/mL. ATCC: American Type Culture Collection. MIC: Minimal Inhibitory Concentration, MBC: Minimal Bactericidal Concentration, ${ }^{*}$ MFC (for Candida albicans) : Minimal Fungicidal Concentration. HS: Hospital Strain.

\section{DISCUSSION}

The results of thin layer chromatography reveal that there is similarity between the chromatographic profiles of the methanolic extracts from the root and the stem bark. However, the extract from leaves has a different chromatographic profile from the other two organs of the plant (Photo 1). This result is consistent with the one obtained from a previous study that showed that the stem bark and the root have similar antioxidant activities and superior to those of the leaves. ${ }^{8}$

The methanolic extracted chromatograms obtained through HPLC showed that there is indeed similarity between the chromatogram from the stem bark extract and that of the root bark extract. However, the chromatogram of the leaves extract is different from that of the stem bark and root extracts Figure 1.

Thin layer chromatography (Photo 1), chromatograms (Fig.1) and mass spectra of the extracts (Fig. 2) carried out on the extracts of the three organs provide sufficient evidence that the stem bark is closer to the roots than the leaves as far as the chemical composition is concerned. Therefore, all the preliminary results obtained made it possible to rule out the possibility of substituting the roots for the leaves. 
The identified substances by GC- MS are shown in Fig. 3. The analysis of extracts containing apolar (semi-volatile) compounds showed that most of the compounds in the root bark and the stem bark extracts were found virtually in leaves extracts except $\alpha$-amyrin. The latter has been identified in the root bark. a total of twelve (12) compounds (1 to 12) in the leaves were identified: six (6) in the root $(1,2,3,4$, 12 and 13) and two (2) in the stem bark (compounds 3 and 4). Compounds such as $\beta$-sitosterol (3) and sitosterol $\alpha$-acetate (4) are found in all three organs of the plant. squalene (8), campesterol (12), stigmasterol (2) and lupeol (1) are found in both the leaves and the root. Research conducted by the team led by Waterman in 1979 allowed its researchers also to detect lupeol and sitosterol in the root of this plant in Mali ${ }^{15}$. Vitamin $E$ is found only in the leaves. All its identified molecules have very interesting pharmacological and biological activities. Lupeol (1) has various pharmacological activities. This compound has been reported to be antioxidant and anti-inflammatory ${ }^{16}$. Isolated stigmasterol (2) from Azadirachta indica has a chemopreventive effect on skin cancer in Swiss albino mice ${ }^{17}$. It has an anti-tumoral, hypoglycemic, antioxidant, and anti-inflammatory effect ${ }^{18}$. $\beta$-sitosterol (3) is known as an antipyretic, an excellent anti-inflammatory ${ }^{19}$. Campesterol has chemopreventive effects against many cancers, including breast cancer ${ }^{20}$. Vitamin $\mathrm{E}$ (alpha-tocopherol (5)) is one of the most important natural antioxidants, protecting polyunsaturated fatty acids in cell membranes ${ }^{21}$.

$\alpha$-Amyrin (13) is a bioactive compound commonly found in leaves, bark and resins. Extensive research over the last four years has identified $\alpha$-amyrin in several plants. This compound has various in vitro pharmacological activities against inflammation, microbial infections and cancer cells $^{22}$. The phytosterols identified in the three organs of the plant are used in the diet for the reduction of cholesterol levels in the blood ${ }^{23}$.
The Togolese species is not toxic and according to the literature, it is intended for consumption ${ }^{24,25}$. Thus, the three organs of $C$. sieberiana would be good in traditional medicine for the reduction of LDL cholesterol in the blood and for the treatment of cancers. GC-MS analyses of the cyclohexane and dichloromethane extracts showed that the chemical composition of the leaves extract was different from that of the stem bark and the root bark. However, the chemical composition of the stem bark extract is very close to those of the root bark extract. These results are also confirmed by the chromatograms of the methanolic extracts of the three organs of the same plant Figure 1.

Indeed, the analysis of the chromatograms showed that there is a similarity between the chromatogram from stem bark extract and that from the root bark extract (Fig. 1). By adding the chromatogram of the leaves extract to the other chromatograms (Fig. 1), it appears from this analysis that the chromatogram of the leaves extract is, for the most part, different from those of the extracts of the stem bark and root bark of the same plant. Thus, the chemical composition of the root methanolic extracts is close to that of the extracts of the stem bark (Photo1). These results are well confirmed by the mass spectrum (DART) performed on the three organs of the plant Figure 2.

The results obtained by the GC-MS analyses of the cyclohexane and dichloromethane extracts of the three organs of the plant showed that the secondary metabolite composition of the extracts of the root bark and the stem bark are close. The metabolites are largely phytosterols that are endowed with biological properties.

GC-MS and thin-layer analyses including chromatograms have shown that the stem bark and root bark are similar in composition to secondary metabolites. Then, the work was directed towards the two organs that are the root bark and the stem 
bark. For this purpose, the LC-MS/MS method for identifying non-volatile compounds was used. Results from LC-MS/MS analyses showed that the chemical composition of the root bark methanolic extracts and the stem bark are very close.

In addition, all the molecules identified in the methanolic extract of stem bark are also found in the root bark extract (Fig. 2). These are: emodin (14), luteolin (15), ( \pm ) -catechin (16), naringenin 5-O-rhamnoside (17), chaetochromine (18), guibourtinidol- (4 alpha-> 6) - catechin (19) and epiafzelechin (20). The latter has already been isolated by Kpegba et al. ${ }^{4}$ from the ethanolic extract of the $C$. sieberiana root bark of Togo. These results are confirmed by thin layer chromatography (Photo1) performed on the two methanolic extracts (root bark and stem bark) as well as their HPLC chromatogram (Fig. 1). These compounds identified in the two organs of the plant belong to the family of flavonoids except emodin which belongs to the family of anthraquinones. These secondary metabolites confer on the plant biological activities.

Emodin (14) has been reported to have a number of biological activities such as anti-diabetic, anti-inflammatory and anti-cancer effects ${ }^{26}$. Previous studies reported that administration of luteolin (15) significantly reduces body weight in mice fed with high-fat foods ${ }^{27}$. Noormandi et al., in their studies of substances from the GreenTea extract, showed that the catechin (16) isolated from this plant inhibits the growth of bacteria ${ }^{28}$. Chaetochromine (18) has powerful and long-lasting antidiabetic activity in mice ${ }^{29}$. The result obtained in this study corroborates the use of $C$. sieberiana in the treatment of diabetes in African traditional medicine ${ }^{30,31}$. This indicates a good knowledge of traditional healers. (-) - Epiafzelechin (20) showed significant anti-inflammatory activity on carrageenan-mediated mouse paw edema ${ }^{32}$. In addition, studies have revealed that this molecule isolated from the root bark of $C$. sieberiana ${ }^{4}$.
All the results obtained through the LC-MS/ MS showed that the methanolic extracts from the root bark and the stem bark are close because all the molecules identified in the extract of the root bark are also found in the extract of the stem bark. These identified molecules have very interesting biological properties which justify multiple uses in traditional medicine of the plant. Thus, the antioxidant activities of extracts of $C$. sieberiana would be related in part to polyphenols, including flavonoids and emodin identified in the root bark and stem of the plant. All the molecules identified from the root bark and stem are grouped in Table 3. This table makes it possible to better compare all the molecules identified in each organ of the plant with the chromatographic methods (GC-MS and LC-MS/MS). Twelve (12) molecules were identified in the root bark and eight (8) identified in the stem bark. Lupeol, stigmasterol, campesterol and $\alpha$-amyrin could not be identified in the stem bark. But the large number of identical molecules identified in both bodies suggests, from the point of view of the chemical composition, that these two bodies are close.

All the molecules identified in this study do not constitute the complete chemical composition of the extracts (Tables 1, 2 and 3). They have also been identified and isolated in many Cassia. Each of them has biological activities of its own. This is why $C$. sieberiana is used traditionally to treat several pathologies ${ }^{3,4}$.

The methanolic extracts of the three plant organs show varying antimicrobial activity on Gram-negative and Gram-positive bacteria and on yeasts. These activities are due to the presence of the flavonoids contained in each of the three organs of the plant (Table 2). Flavonoids are known for their antimicrobial properties and according to the literature, there is a close relationship between flavonoid compounds and antibacterial activities ${ }^{32}$. 
As a matter of fact, the methanolic extracts of the root bark and the stem bark have activities on the same microbial species, namely $S$. aureus, S. typhimurium and K. pneumoniae. This finding is explained by the fact that the two organs of the plant have a very similar chemical composition as shown by the results of thin layer chromatography (Photo 1). In addition, the methanolic extract of the root bark has a bacteriostatic effect on the strains of $S$. typhimurium whereas that of the bark gave no effect. This difference may be due to the additional presence of $\alpha$-amyrin (13) in the root bark that is absent in the stem bark. This molecule has known antimicrobial properties ${ }^{22}$, so its presence in the methanolic extract could potentiate the observed bacteriostatic effect.

The methanolic extract of leaves has antibacterial activity with greater inhibition diameters than those given by the methanolic extracts of root bark and stem bark. Although its effect on E. coli is not significant, it is the only extract to have an inhibitory action on this bacterium. In addition, it has an antifungal activity (on C. albicans) that the other two methanolic extracts (root bark and stem bark) do have. It has a greater antimicrobial activity than the methanolic extracts of the root bark and stem bark.

This potent antimicrobial effect of the methanolic extract from Cassia sieberiana leaves is confirmed by the types of antimicrobial effect. Indeed, the methanolic extract from the leaves gave bactericidal effects on all the strains to which it is sensitive with MICs and MBCs lower than those given by the methanolic extracts of the root bark and the stem bark. This finding is explained by the fact that the leaf of $C$. sieberiana has a chemical composition very different from that of the root bark and the stem bark (Photo 1 and Fig. 2). It could also be explained by the fact that the leaves being more exposed to the environment expose themselves more to the aggressors and develop defense mechanisms vis-à-vis the microorganisms than do the other organs of the same plant.

The results confirm the traditional use of $C$. sieberiana organs in microbial infections. Leaves with satisfactory antimicrobial activity would be better recommended for the control of microbial infections.

\section{CONCLUSION}

The results of the analysis have clearly shown that the root bark and the stem bark are close by their chemical composition. The molecules in the methanolic extracts of the plant are important in the treatment of certain bacterial infections; and the methanolic extract of the leaves is also of importance in the treatment of mycotic infections. These biological results allow a rational explanation of ancestral practices. The use of stem bark as a substitute for root bark in traditional medicine would contribute to the preservation of the species and biodiversity.

\section{ACKNOWLEDGEMENT}

We are thankful to members of Pharmacognosie laboratory, UMR CNRS 6014 of the Faculty of Pharmacy of Rouen (France), the Department of Life and Environmental Sciences of the University of Cagliari (Italy), the Agence Universitaire de la Francophonie (AUF) for their support.

\section{Conflict of interests}

The authors state that there is no conflict of interest in this work.

\section{REFERENCES}

1. Khaldi, A.; Meddah, B.; Moussaoui, A.; Benmehdi, H.; Gouri, S. European Journal of Scientific Research., 2012, 80, 311-321.
2. Ajayi, C.O.; Funso-Babarimisa, F.; Elujoba, A.A. Afr J Tradit Complement Altern Med., 2014, 11(4), 44-47. 
3. Khan, M.E.; Ugbede; Odokpe, A.;Tor-Anyiin, T.A. Prog. Chem. Biochem. Res., 2019, 2, 143-149.

4. Kpegba, K.; Agbonon, A.; Petrovic, A.G.; Amouzou, E.; Gbeassor, M.; Proni, G.; Nesnas, N. J. Nat. Prod., 2011, 74(3), 455459.

5. Diarra, N.; Klooster, C.V.; Togola, A.; Diallo, D.; Willcox, M.; Jong, J. D. J. Ethnopharmacol., 2015, 166, 352-360.

6. Leteane, M.M.; Ngwenya, B.N.; Muzila, M.; Namushe, A.; Mwinga, J.; Musonda, R.; Moyo, S.; Mengestug, Y.B.; Abegaze, B.M.; AndraeMarobela, K. J. Ethnopharmacol., 2012, 141 48- 56.

7. Fall, A.D.; Gbati, O.B.; Diatta, W.; Lapo, R.A.; Diatta-Badji, K.; Dieng M.; Dieng S.I.M.; Bassene, E; Pangui L. J. Eur. J. Med. Plants., 2016, 11, 1-7.

8. Evenamede, K.S.; Kpegba, K.; Simalou, O.; Boyode, P.; Agbonon, A.; Gbeassor, M. Int. J. Biol. Chem. Sci., 2017, 11(6), 2924-2935.

9. Donkor, K; Okine, L.N.K.; Abotsi, W.K.M.;Woode, E. Pharmacologia., 2013, 4, 301-310.

10. Salou, M; Ekoue-Toulan, D.E; Dossim, S.; Agbonon, A. Afr. J. Microbiol. Res., 2019, 13, 55-59.

11. Afanyibo, Y.G.; Anani, K.; Esseh, K.; Sadji, Y.; Idoh, K.; Koudouvo, K.; Agbonon, A.; Améyapoh, Y., Tozo, K.; Gbeassor, M. OALib Journal., 2018, 5, 1-13.

12. Benmeziane, F., Djermoune-Arkoub L.; Hassan K. A., Zeghad H. Int. Food Res. J., 2018, 25, 561-564.

13. Kouadio, N.J.; Guessennd, N.K.; Kone, M.W.; Moussa, B.; Koffi, Y.M. Int. J. Biol. Chem. Sci., 2015, 9, 1252-1262.

14. Anani, K.; Adjrah, Y.; Ameyapoh, Y.; Karou, S.D.; Agbonon, A.; De Souza, C.; Gbeassor, M. Pharmacogn. Res., 2016, 8, 142-146.
15. Waterman, P.G.; Faulkner, D.F. Planta Med., 1979, 178-191.

16. Ruiz-Rodríguez, M.A; Vedani, A.; FloresMireles, A.L.; Chairez-Ramirez, M.H; Gallegos-Infante, J.A; Gonzalez-Laredo, R.F. Chem. Res. Toxicol., 2017, 30, 1562-1571.

17. Ali, H.; Dixit S.; Ali, D.; Alqahtani, S.M.; Alkahtani, S.; Alarifi, S. Drug Des Devel Ther., 2015, 9, 2793-2800.

18. Kaur, N.; Chaudhary, J.; Jain, A.; Kishore, L. IJPSR., 2011, 2(9), 2259-2265.

19. Patil, B.; Rajput, A. J. Pharm. Res., 2012, 5, 1228-1230.

20. Shahzad, N.; Khan, W.; Md, S; Ali, A.; Saluja,. S.S; Sharmad, S.; Al-Allaf, F.A.; Abduljaleel, Z.; Ibrahim, I.A.A.; Abdel-Wahaba, A.F.; Afify, M.A.; Al-Ghamdia, S.S. Biomed. Pharmacother., 2017, 88, 786-794.

21. Aeschimann, W; Stefanie, Staats; Kammer, S.; Olieric, N.; Jeckelmann, J-M.; Fotiadis, D.; Netscher, T.; Rimbach, G.; Cascella, M.; Stocker A. Sci Rep., 2017, 4970, 1-13.

22. Sob, S.V.; Wabo, H.K.; Tchinda, A.T.T.; Tane, P.; Ngadjui, B.T.; Ye, Y. Biochem. Syst. Ecol., 2010, 38, 342-345.

23. Bruneton, J. Pharmacognosie, Phytochimie, Plantes Médicinales TEC \& DOC ed., 2016, Paris (France). 1504.

24. Von Maydell, H. J. Arbres arbustes du Sahel, leurs caractéristiques leurs utilisations. Germany: Publication., 1983, 147.

25. Evenamede, K.S.; Kpegba, K.; Idoh, K.; Agbonon, A.; Simalou, O.; Boyode, P.; Oke, O. E.; Gbeassor, M. J. Appl. Biol. Biotechnol., 2019, 7, 47-52.

26. Chen, J.; Li, S.; Liu, M.; Lam, C.W.K.; Li, Z.; Xu, X.; Chen, Z.; Zhang, W.;Yao, M. Front. Pharmacol., 2017, 8, 1-11. 
37. Xu, N.; Zhang, L.; Dong, J.; Zhang, X.; Chen, Y.G.; Bao, B.; Liu, J. Mol. Nutr. Food Res., 2014, 58, 1258-1268.

28. Noormandi, A.; Dabaghzadeh, F. J. tradit. complement. Med., 2015, 5, 15-20.

29. Qiang, G.; Xue, S.; Yang, J.J.; Du, G.; Pang, X.; Li, X.; Goswami, D.; Griffin, P.R.; Ortlund, E.A.; Chan, C.B.; Ye, K. Am Diabetes Assoc.,
2014, 63, 1394-1409.

30. Shinkafi, T. S.; Bello, L.; Hassan, S.W.; Ali, S. J. Ethnopharmacol., 2015, 172, 91-99.

31. Amuri, B.; Maseho, M.; Simbi, L.; Okusa, P.; Duez, P.; Byanga, K. Phytother. Res., 2017, 31(7), 1029-1033.

32. Djahra, A.B.; Bordjiba, O.; Benkherara, S. Rev. Sci.Technol., Synthèse., 2012, 24, 29-37. 